\title{
Yemen's rhino horn trade increases
}

\author{
Lucy Vigne and Esmond Bradley Martin
}

The authors visited Yemen on behalf of WWF International in April 1992 to find out what had been happening to the rhino horn trade since their last visit to the country during the Gulf Crisis in November 1990. From 1985 to 1990, Yemen's rhino horn imports had decreased very sharply compared with the 1970 s and early 1980s. From August 1990 to March 1992, however, a considerable increase in imports occurred, with just over $750 \mathrm{~kg}$ of rhino horn being brought into Yemen. The reason for the increase was not a rise in the wholesale price of rhino hornthis is still half that paid in Taiwan. The main reason for the increase is that new and easier trade routes have opened up, primarily from Tanzania by air to Saudi Arabia or the United Arab Emirates and then overland to Yemen.

\section{Smuggling routes through Africa}

The remnants of Africa's black and white rhino populations, totalling about 8200 (IUCN/SSC, 1992), survive primarily in eastern and southern Africa, especially Kenya, Tanzania, Zimbabwe, South Africa and Namibia. Zimbabwe, which in the mid-1980s had the largest remaining black rhino population, today has only 430 (IUCN/SSC, 1992). Since 1984, more than 1100 carcasses of poached rhinos have been found, almost all black (Zimbabwe's Department of National Parks, 1992) and it is in Zimbabwe that the worst rhino poaching is still occurring. More than 160 poachers, mostly Zambian citizens, have been killed there since 1984 (Zimbabwe's Department of National Parks, 1992). In 1990 and 1991 more than 325 rhinos (nearly all black) were illegally shot dead and their horns removed. During this 2-year period the main smuggling route for this horn, according to various sources (including the South African police), had been north to Zambia's capital, Lusaka, and then by road to South Africa or by air to Swaziland. Taiwanese businessmen bought the horn in southern Africa for \$US500-750 a kg for export to Taiwan, where they could sell it for about \$US2000 a kilo. In contrast, since the $1970 \mathrm{~s}$, rhino horn originating in eastern Africa has mostly been sent by dhow or aeroplane directly to Yemen (Martin, 1987).

Although Taiwan has been the major importer of African rhino horn since 1985, it is probable that Yemen was the major importer in 1991. Did this horn originate in eastern Africa? Or is it possible that smuggling routes were changing in southern Africa and that some of the horn from the large number of rhinos poached in Zimbabwe reached Yemen in 1991? This latter possibility could result from South Africa's new special police unit, which is successfully tackling their smuggling problem. Many rhino horn deals have been intercepted recently in South Africa. To avoid being caught by the South African authorities, the middlemen may instead be moving some of the Zimbabwean horn from Lusaka, by rail or road to Tanzania, and onwards by air or dhow to the Arabian peninsula. Northern Mozambique also still has some rhinos, and horn could easily be crossing the border into Tanzania destined for Yemen. Another possible source of the horn is Burundi, which could well have old stocks because it was a major entrepôt in the mid-1980s. In Kenya, only three rhinos are known to have been poached in 1991 and just one of these animals had its horns removed. Horn reaching Yemen is therefore unlikely to be of Kenyan origin. Little is known about Sudan. The country 
could have small quantities of old stocks that are gradually being sold. Sudanese businessmen told us that the Sudanese army is killing some of the remaining rhinos in southern Sudan and bringing the horns north to Omdurmân for sale, while the Sudan People's Liberation Army is also killing some and taking horns to sell in Nairobi.

Some of the new rhino horn reaching Yemen may well originate in Tanzania. There are probably more black rhinos surviving in the Selous Game Reserve than most estimates suggest (A. Laurie, pers. comm.) and more of these animals could have been poached than has been recorded. Another source of this horn may be from Operation Uhai, a major government effort in and around the Selous to capture poachers and traders. During its 21month anti-poaching campaign in Tanzania, which ended in March 1991, more than 290 rhino horns were recovered (J. Thomsen, pers. comm.). The Tanzanian authorities are currently investigating these stockpiles of horn. It is probable that the new horn reaching Yemen originates from a combination of most of these sources, but especially from Tanzania, Sudan, Mozambique and Zimbabwe. With a recent deterioration in law enforcement in certain African countries, smuggling rhino horn through Africa has become easier.

\section{Saudi Arabia and the United Arab Emirates as entrepôts for rhino horn}

Whatever the origins of this African rhino horn, Yemeni traders now say that the easiest way to get a large quantity of the horn into Yemen is to send it by air to the Gulf and then transport it by lorry overland to Yemen. This has become a new and major way to move the horn. In the past, most horn was flown directly into Sanaa or carried by dhow to the Yemeni. coast. The person who trades 85 per cent of rhino horn in Yemen, who calls himself 'the king of the rhino horn business', told our informer in Sanaa in April 1992 that the best way for him to get large amounts of horn from Africa was via a contact address he could provide in Saudi Arabia. From there other traders would smuggle the horn by lorry into Yemen. He himself does not import it and thus does not risk breaking the law that has prohibited the import of rhino horn since August 1982. The United Arab Emirates (UAE) is another main entrepôt. This same trader told our informer that in 1991 he had obtained $200 \mathrm{~kg}$ of rhino horn, which Koreans had brought by air from Dar es Salaam to Sharjah in the UAE. Yemenis then took these horns overland to Sanaa. Unlike Saudi Arabia, the UAE is a member of CITES, and the government has on the whole severely clamped down on the trade in ivory and rhino horn since its scandalous role as a major entrepôt for these products in the late 1980s (Martin, 1992). However, wildlife trade law enforcement in the Emirate of Sharjah is not, as yet, nearly tight enough.

It is relatively easy to smuggle rhino horn overland into Yemen, because lorries carry goods back and forth all the time and smuggling generally is very common. According to officials in the Ministry of Supply and Trade, 30 per cent of imported goods are smuggled into Yemen to avoid the high taxes: cars, televisions, videos, watches, clothes, shoes and many more items. The unification of South and North Yemen in May 1990 gave the country a much longer land boundary. Because Yemen is adjacent to several rich Arab countries where many Yemenis live, smuggling of goods can be easily arranged. There are large stretches of desert, which are not policed, and vehicles are driven across the roadless stretch of sand into Yemen through unpatrolled borders.

\section{Smuggling of rhino horn into Sanaa by air}

According to Yemeni and Sudanese traders, only small quantities of rhino horn are still smuggled into Sanaa airport, because customs controls have become tighter, and only a few horns at a time can slip through, hidden in personal luggage. The main Sanaa trader tells smugglers not to bring in horn through the airport any more because of stricter security. Khartoum airport, previously a major exit 
On the right a rhino horn jambia is being polished, while in the centre a salesman awaits customers at his jambia stall in the souk (Lucy Vigne).

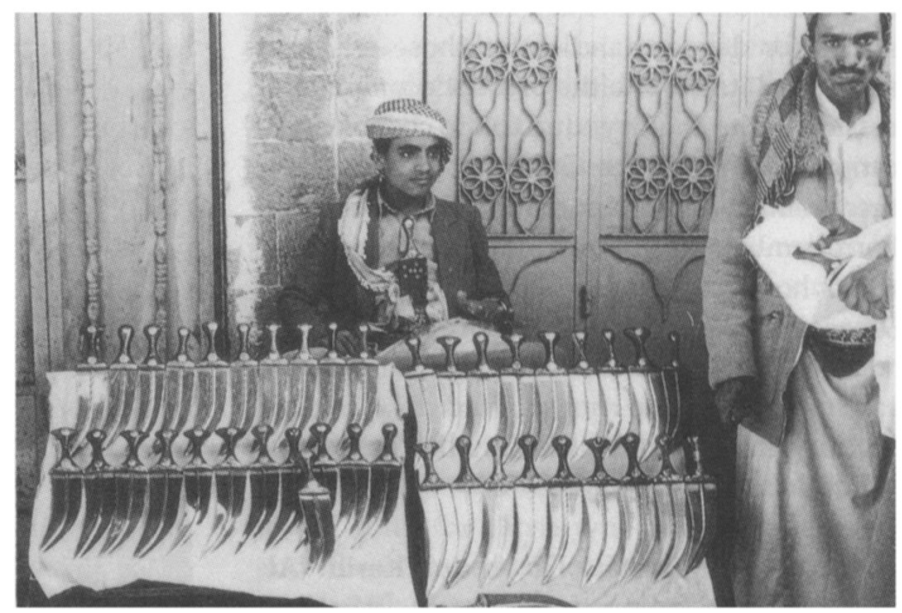

point from Sudan for rhino horn, also has tighter controls. One Sanaa trader admitted to our informer that he had just been in Khartoum for the third time to buy rhino horn. He had bought two horns weighing 2 and $5 \mathrm{~kg}$, respectively, for $\$ U S 250$ a $\mathrm{kg}$, but had failed to get them through Khartoum airport and had to leave them with a friend to try to smuggle them out of the country later. Yemeni and Sudanese middlemen know that they can buy rhino horn and other wildlife products in Omdurmân, particularly in the antique shops, where wildlife commodities are often hidden at the back of shelves. In order to try to stop rhino horn, ivory and cat skins from leaving Sudan, customs officials are now regularly changed at Khartoum airport to minimize the possibility of corruption. In September 1991, however, a Sudanese Arab (a business colleague of our informer) succeeded in bringing a $1.5-\mathrm{kg}$ horn in his luggage through Khartoum airport to Sanaa. He sold the horn in the souk for 30,000 rials (\$US1000 a $\mathrm{kg}$ ).

One of the reasons that Dar es Salaam airport is today the main point of exit for rhino horn in eastern Africa is that policing measures are simply not adequate there. Although the great bulk of the horn leaving Tanzania is flown to Saudi Arabia or the UAE before being forwarded to Yemen, according to the main trader, some goes direct to Sanaa. One Yemeni trader in Sanaa said he had re- ceived and used $12 \mathrm{~kg}$ of rhino horn in 1991, all brought from Dar es Salaam to Sanaa airport. A member of his family had gone to Dar es Salaam to buy tea, and on one visit had brought back four horns weighing a total of 7 $\mathrm{kg}$, and on another, three horns weighing a total of $5 \mathrm{~kg}$. The trader told us that he had met his relation at Sanaa airport with a bribed customs officer who did not search his bag.

It is no longer profitable to smuggle the odd rhino horn into Sanaa by air, so those involved have other purposes for their journey. An importer of rhino horn generally receives $\$$ US1000 per $\mathrm{kg}$. Although the dealer will pay for it in rials, it is easy for the importer to change rials into dollars with the souk money changers. In dollars, the price for rhino horn has remained the same since 1985 , but because of the devaluation of the rial, in local currency the price has risen almost 300 per cent (Table 1).

\section{Yemen's domestic market for rhino horn jambias}

In the souk, it was discouraging to find that there were more new dagger (jambia) handles made of rhino horn than had been available in the late 1980s. This supports the belief that there was a significant rise in rhino horn imports after late 1990. In Yemen, it appears that increased westernization has not reduced people's demand for jambias and rhino horn 
continues to be the most sought after substance for dagger handles for those who can still afford it. Despite the present economic recession in the country, due to the cost of unification in 1990 and the Gulf War in early 1991, there remain enough potential buyers of rhino horn jambias to exceed the availability of rhino horn in Yemen. Thus, the traders in Sanaa are always in need of more horn.

\section{Meetings and action plans with Yemeni officials}

The Foreign Minister, Dr Abdul Karim AlIryani, is very concerned about the plight of the rhino and Yemen's major role in the trade in rhino horn. In April 1992, during an hourlong meeting with us at his house, he said that the information we brought him about the upsurge in Yemen's rhino horn imports was, 'very new to us and very sad'. He responded by composing a draft decree, which stated that the domestic trade in raw (unworked) rhino horn would be banned, and a stock-taking would be carried out. Later, inspectors could make surprise checks on dealers' rhino horn supplies so that any unrecorded material could be confiscated and stiff penalties applied. Dr Al-Iryani decided to arrange for the main trader in rhino horn to be called into the Ministry of Supply and Trade to be given this decree personally and warned strongly to desist from dealing in rhino horn.

This decree prohibiting internal trade in raw rhino horn will be a major step forward. At present, once rhino hom enters the country it is perfectly legal. A ban on the possession of new rhino horn could be very effective, if properly enforced. The souk, where most rhino horn handles are produced, is only a few hundred square metres in size and would be easy to monitor. It would be impossible to prohibit the sale of rhino horn handles, because this could never be enforced, but raw rhino horn could be monitored successfully.

During our previous visit to Sanaa, in 1990, two important plans for action were discussed with the Foreign Minister, namely, joining CITES and issuing a religious edict stating that the trade in raw rhino horn was against the will of God. However, due to several factors - the Gulf War, the unification of Yemen, severe economic problems, and the move towards democracy - the rhino horn issue became a low priority for the government. During our 1992 meeting with the Foreign Minister, the importance of CITES and the religious edict were discussed again and $\mathrm{Dr} \mathrm{Al}-$ Iryani told us that he would follow them up to

\begin{tabular}{|c|c|c|c|c|}
\hline \multirow[b]{2}{*}{ Year } & \multirow{2}{*}{$\begin{array}{l}\text { Weight } \\
(\mathrm{kg})\end{array}$} & \multicolumn{2}{|c|}{ Price paid per $\mathrm{kg}$} & \multirow{2}{*}{$\begin{array}{l}\text { Exporting } \\
\text { African countries }\end{array}$} \\
\hline & & Rials & \$US & \\
\hline 1980 & 1050 & 3500 & 764 & $\begin{array}{l}\text { Tanzania, Kenya, } \\
\text { Ethiopia, Somalia }\end{array}$ \\
\hline 1981 & 1320 & 3500 & 764 & $\begin{array}{l}\text { Tanzania, Ethiopia, } \\
\text { Sudan }\end{array}$ \\
\hline 1982 & 1585 & 3600 & 786 & $\begin{array}{l}\text { Tanzania, Ethiopia, } \\
\text { Sudan }\end{array}$ \\
\hline 1983 & 1120 & 4100 & 891 & Kenya, Sudan \\
\hline 1984 & 1058 & 4300 & 796 & Tanzania, Somalia \\
\hline 1985 & 475 & 8300 & 1150 & Ethiopia, Sudan \\
\hline 1986 & 100 & 10,000 & 1032 & Sudan \\
\hline 1987 & c. $200-300$ & c. 12,000 & c. 1035 & Tanzania, Kenya, Sudan \\
\hline 1988 & c. $200-300$ & c. 12,400 & c. 1035 & Tanzania, Kenya, Sudan \\
\hline 1989 & c. $200-300$ & c. 13,000 & c. 1035 & Tanzania, Kenya, Sudan \\
\hline 1990 & c. 333 & 15,000 & 1040 & Tanzania, Kenya, Sudan \\
\hline 1991 & c. 450 & 30,000 & 1035 & Tanzania, Kenya, Sudan \\
\hline
\end{tabular}

Source: personal records of and personal communication with the main trader.
Table 1. Quantities and values of rhino horn bought from 1980 to 1991 by the main trader in Yemen, who handled over 80 per cent of the business 


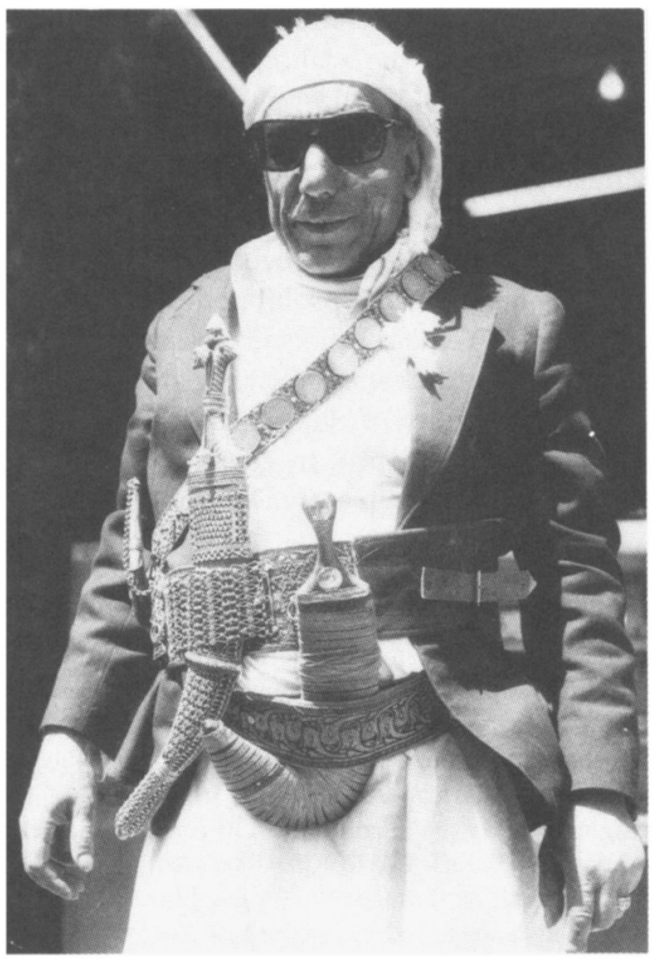

A salesman shows off his two antique Yemeni jambias to a potential buyer (Esmond Bradley Martin).

completion. Furthermore, he suggested that a short film about the plight of the rhino could be shown on Yemeni television in order to raise public awareness. This film is currently being made in London in the Arabic language.

Because information about Africa's devastated rhino populations is lacking in Yemen, other information campaigns were discussed. An influential member of the Ministry of Information, and the Editor of the Yemen Times both offered to increase publicity on the rhino. The Professor of Biological Sciences at Sanaa University is currently in charge of redesigning school curricula and he agreed to incorporate information on the disastrous effects of the rhino horn trade. This could be a very promising way of persuading the younger generation not to buy rhino horn jambias.

Our final official meeting was with the Minister of State, Mohsen Ali Al-Hamdani, who is also the Chairman of the Environment Protection Council in Sanaa. We agreed that the WWF would supply him with information on rhinos for the Council to disseminate. It was also decided to hold a seminar for the traders and officials, to which we were invited, in order to encourage the traders to use substitutes for their dagger handles. The rhino horn trade is no longer a big money-maker in Yemen; there are too many costs, such as bribes, to make it very profitable. No craftsmen would lose jobs because the demand for jambias with buffalo horn and plastic handles continues. Old and antique rhino horn jambias are regularly repaired and sold in abundance in the souk for those who really want them, and these are more valuable anyway than those with new rhino horn handles. Also, the craftsmen could make water buffalo horn jambias more valuable by adding, for example,

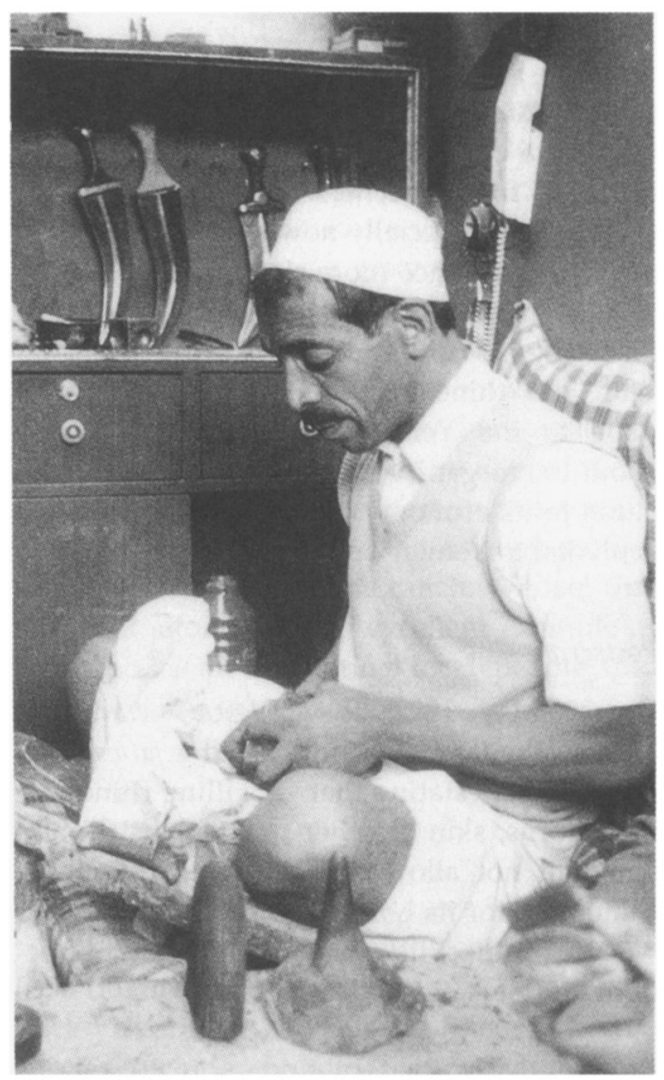

In 1990 a jambia craftsman allowed us to photograph two rhino horns - as seen in the foreground an extremely rare sight because rhino horn imports are illegal (Lucy Vigne). 
gold decoration. Only through discussions with all interested parties can problems be understood, and, it is hoped, be solved.

\section{Conclusion}

The long-term solution to stopping importation of rhino horns into Yemen must be a combination of approaches. These include promoting public awareness in Yemen, a ban on the possession of raw rhino horn within the country, further use of substitutes, and increased efforts at law enforcement to halt Yemen's domestic and international rhinohorn trade. Concerning the closure of trade routes, Arab countries that act as entrepôts must co-operate, and greater vigilance at all the airports involved in smuggling is imperative. Trade routes through and out of Africa, and the individual dealers who use them, must be identified and intercepted. Also, of course, rhinos need better protection in situ. Only by a concerted effort can Africa's rhinos be saved from poachers. Yemen has a major role to play, especially now that its rhino horn imports have once more risen. The country is very keen to improve its international image, following its unpopularity during the Gulf War. The rhino horn trade may be a small issue to the Yemen Government which is about to reorganize its constitution, and in relation to its economy. But it is an issue which is pivotal to Yemen's reputation world-wide.

\section{Postscript}

On 20 May 1992, the religious leader of Yemen, the Grand Mufti, issued a fatwa (religious decree) stating that '.. killing rhinos for their horns, skin or other purposes is prohibited and not allowed. Therefore, killing the rhinoceros for its horn must be prevented and we must protect its existence and allow it freedom until its natural death'.
On 2 December 1992, after another visit to Sanaa by one of the authors (E. B. M.) as the United Nations Environment Programme's Special Envoy for rhino conservation, the Ministry of Supply and Trade issued a decree, effective from that date, stating that trading of rhino horn that has not been processed into dagger handles is prohibited within the Republic of Yemen. Whoever possesses rhinohorn in its natural state must register the horn with the Ministry of Supply and Trade. This decree was published in the Yemeni newspaper, Al-Thawrah, in early December 1992.

\section{Acknowledgments}

Thanks are due to WWF-International for its financial support for this work, and to the US Embassy in Nairobi and the US Embassy in Sanaa for their assistance. We would especially like to thank the American Ambassador in Sanaa, Arthur Hughes, and the Economic Officer of the US Embassy in Sanaa, David Katz. We are also grateful to the British Ambassador in Sanaa, Mark Marshall, for his continuing help over the last 4 years. Thanks are also due to the officials in Yemen who gave us so much time, especially the Foreign Minister, Dr Al-Iryani, and the Minister of State, $\mathrm{Mr} \mathrm{Al}$ Hamdani.

\section{References}

IUCN/SSC. 1992. African Rhino Specialist Group Meeting, 'African Rhino Populations', formulated at Victoria Falls, Zimbabwe, 17-22 November 1992 (unpublished)

Martin, E. B. 1987 The Yemeni rhino horn trade. Pachyderm, No. 8, 13-16.

Martin, E. B. 1992. Ivory, rhino horn and other wildlife trade in the United Arab Emirates. Swara, 15 (4), 25-27.

Zimbabwe's Department of National Parks and Wild Life Management. 1992. Operation Stronghold Statistics. Harare, 22 September 1992 (unpublished).

Lucy Vigne and Esmond Bradley Martin, PO Box 15510 Mbagathi, Nairobi, Kenya. 